\title{
Gene Silencing in Horticultural Transgenic Plants: Mechanisms, Technologies and Applications in Horticultural Crops
}

\author{
S. Choudhary ${ }^{1}$, S. K. Barolia ${ }^{1 *}$, R. Sharma ${ }^{2}$, R. S. R. Krishnan ${ }^{3}$, \\ M. R. Hindala ${ }^{4}$ and M. Sewda ${ }^{4}$
}

${ }^{1}$ ICAR-National Research Centre on Seed Spices Tabiji Ajmer, Rajasthan, India

${ }^{2}$ Biotechnology Centre, Jawaharlal Nehru Krishi Vishva Vidhalya, Jabalpur (Madhya Pradesh) India

${ }^{3}$ Jawaharlal Nehru Krishi Vishva Vidhalya, Jabalpur (MP) India

${ }^{4}$ Department of Botany, University of Rajasthan, Jaipur, India

*Corresponding author

\section{A B S T R A C T}

\begin{tabular}{l} 
K e y w o r d s \\
Anti-sense \\
transgenes, DNA \\
and RNA viruses, \\
Flower color, \\
modification, \\
Parthenocarpy, \\
Post-transcriptional \\
gene silencing, \\
Sense transgenes, \\
Transgenic plants \\
Virus resistance \\
\hline $\begin{array}{l}\text { Article Info } \\
\text { Accepted: } \\
10 \text { October } 2020 \\
\text { Available Online: } \\
10 \text { November } 2020\end{array}$ \\
\hline
\end{tabular}

Using RNAi technique, two ripening-specific ethylene-induced $\mathrm{N}$-glycoprotein modifying enzymes, $\alpha$-mannosidase ( $\alpha$-Man) and $\beta-\mathrm{D}-\mathrm{N}$ -

\section{Introduction}

\begin{abstract}
The gene silencing in horticulture transgenic crops is too crucial to know about the internal mechanism of plant at genomic level. Horticulture involves a variety of plants and crops including fruit, vegetables, spices, and ornamental plants. Gene silencing refers to the ability of a cell to prevent the expression of a certain gene. With the cleavage or translational repression of the messenger RNA (mRNA) molecules, the genes that form them are essentially inactive. Horticultural plants have evolved a variety of gene silencing pathways in which small RNAs (20-30 nucleotides) repress the expression of genes at the transcriptional or post-transcriptional level. Gene silencing using RNA interference technology, transcriptional gene silencing, and virus-induced gene silencing has been used in horticultural crops. The presence of double-strand RNAs inside the cell lead to the production of small interfering RNAs, short hairpin RNAs, and micro-RNAs. The production of their RNAs leads to the silencing of mRNA (actual protein coating RNA). This technique is a very effective experimental tool to silence specific genes for better stress tolerance, enhance insect/pest/pathogen resistance, and improve nutritional status. This technique and mechanism can be controlled by artificial means and applied for the improvement of cultivars of a variety of horticultural crops.
\end{abstract}


ripening (Molesini et al., 2012; Karlova et al., 2013). The recent study shows that CNR is also negatively regulated by APETALA2a (a target of miR172). One way, it positively regulates fruit ripening. In another way, it negatively regulates ethylene synthesis (Karlova et al., 2013). The silencing of ripening-related chalcone synthase (CHS) gene in strawberry fruits (Fragaria $\mathrm{x}$ ananassa cv. Elsanta) by a ihp-RNA construct containing the partial sense and corresponding antisense sequences of CHS separated by an introns obtained from a F. ananassa quinone oxidoreductase gene. The reduced levels of CHS mRNA and enzymatic CHS activity, the levels of anthocyanins were down-regulated and precursors of the flavonoids pathway were shunted to the phenylpropanoid pathway leading to large increases in levels of (hydroxy) cinnamoyl glucose esters. This technique in combination with metabolite profiling analysis will be useful for the development and ripening of strawberry fruit (Hoffman et al., 2006).

\section{RNAi for an enhancement of shelf life}

Horticultural crops are more prone to postharvest losses and deterioration in the quality and economic viability of many plant species. India is the largest producer of horticultural crops and $\sim 30 \%$ post harvest losses in fruits and vegetables is due to spoilage (Agricultural Research Data Book, 2004). Therefore, there is an urgent need to increase shelf life of horticultural crops to minimize the deterioration and post harvest losses. The traditionally farmers used to harvest green fruits and middle man/ sale personal spray ethylene to fetch higher prices of ripen fruits but there is substantially decrease in flavor content. The shelf life in tomato has been increased by silencing of ethylene producing genes through RNAi technology. As tomato being a climacteric fruit, has autocatalytic activities of ethylene during its ripening period. Therefore, an increase in self life or delaying in ripening process can be achieved by introduction of ACC oxidase ds RNA in tomato which suppress the expression of ethylene genes. In transgenic tomato plants targeting more homolog than a single unit of ACC oxidase (1aminocyclopropane -1carboxylate) by using RNAi technology during ripening stage would be more effective rather than single homolog (Gupta et al., 2013). The chimeric RNAi-ACS construct designed to target ACS homologs, effectively repressed the ethylene production in tomato fruits enhanced the tomato self-life by 45 days in tomato.

The ethylene suppression brings compositional changes in the fruits by enhancing polyamine (PA) levels. At same time, decreased levels of ethylene in RNAiACS fruits lead to the altered levels of various ripening-specific transcripts (i.e. upregulation of PA biosynthesis, ascorbic acid (As-A) metabolism genes \& down-regulation of cell wall hydrolysing enzyme genes). The down-regulation of ACS homologs using RNAi can be an effective approach for obtaining delayed ripening with longer shelf life and an enhanced processing quality of tomato fruits, owing to the reduced rate of softening.

The silencing of a ripening-related chalcone synthase (CHS) gene in strawberry fruits (Fragaria $\mathrm{X}$ ananassa CV. Elsanta) by a ihp RNA construct containing the partial sense and corresponding antisense sequences of CHS separated by an intron obtained from a F. ananassa quinone oxidoreductase gene. The reduced levels of CHS mRNA and enzymatic CHS activity, the levels of anthocyanins were down regulated and precursors of the flavonoids pathway were shunted to the phenylpropanoid pathway leading to large increases in levels of (hydroxy) cinnamoyl glucose esters. This technique in combination 
with metabolite profiling analysis will be useful for the development and ripening of strawberry fruit (Hoffman et al., 2006).

\section{RNAi for nutritional quality improvement- Bio-fortification}

Most of the world's population lacks one or more essential mineral elements in his food supplements (White and Broadley, 2009). RNAi being a promising technology in recent year has great potential to improve better quality and nutritional quality traits by modifying the expression of genes. Biofortification of plant using RNAi provides essential elements like $\mathrm{Cu}, \mathrm{Se}, \mathrm{Ca}, \mathrm{Fe}, \mathrm{I}, \mathrm{S}, \mathrm{P}$, $\mathrm{Zn}, \mathrm{Mg}$, etc., (Table 1) and dietary antioxidants such as in tomatoes (Niggeweg et al., 2004). RNAi play key role in development of fruit \& vegetables with seedless-ness with desired agronomic traits, with enhanced nutritional quality such as carotenoid and flavonoids contents, both are highly beneficial for human health. RNAi mediated bio-farming or molecular farming is another approach for production of plant derived proteins, essential oils, starch, vitamins, antioxidants etc. for pharmaceutical industry. RNAi in combination with fruit specific promoter used to suppress an endogenous photo morphogenesis gene DET1 in tomato, a regulatory gene involved in repression of several light signalling pathways. DET1 was effectively degraded in transgenic tomato with suppressed DET1, with the increase in the level of flavonoids and carotenoid content (Davuluri et al., 2005). Abscisic acid (ABA) plays very significant roles at the time of fruit ripening in tomato. The SINCED1 gene in tomato encodes 9-cisepoxycarotenoid dioxygenase, which is an important enzyme in the ABA biosynthesis, was suppressed by RNAi. The fruits showed more accumulation of upstream compounds, chiefly lycopene and $\beta$ carotene from these RNAi lines. Similarly, in apple the fruit quality has been improved by enhanced selflife using RNAi approach (Dandekar et al., 2004), reducing accumulating amount of a major apple allergen (Gilisen et al., 2005) and silencing the leaf sorbitol synthesis process, which affects starch accumulation and sugaracid balance there by the fruit quality. RNAi based production potential of for these products have been published by several authors, some of which related to horticultural crops are discussed in this article.

CaMV 35S promoter-driven hairpin RNAi construct is part of the coding region of the tobacco NtSPP2 gene to reduce SPP expression in transgenic potato tubers (Chen et al., 2008). They reported that Suc6P accumulates in RNAi-silenced sucrose phosphatase (SPP) potato tubers upon cold storage at $4{ }^{\circ} \mathrm{C}$. They have revealed from northern analysis that cold-induced expression of vacuolar invertase (VI) was blocked in SPP-silenced tubers explaining a reduced sucrose-to-hexose conversion. Suc6P levels were found to be negatively correlated with VI expression.

In opium poppy (Papaver somniferum), through the use of this technology the morphine line has been replaced with nonnarcotic alkaloids. RNAi used to interfere with multiple steps of a complex biological pathway. An hnRNA construct was designed ti silence of the multigene codeine reductase (COR) gene family. The transgenic plant accumulated $(\mathrm{S})$ recticuline, a precursor nonnarcotic alkaloid which occur seven enzymatic steps up stream of codeinone in the pathway. It occurs at the expense of morphine, codeine, opium and baine (Allen et al., 2004).

In sweet potato (Ipomoea batabas), the range in amylose contents is narrow (10 - 25\%) compared with other crops. The amylose content has been markedly increased utilizing 
this approach by suppressing the expression of endogenous IbSBEII gene. The introduction of construct encoding dsRNA of SBEII into sweet potato genome to inactivate IbSBEII gen, which resulting in increase in apparent amylose content in the sweet potato starch. The ratio of amylose to amylopectin has a great influence on the physicochemical properties of starch. It the improved sweet potato has new dietary and industrial applications. Similarly, in potato through the use of RNAi approach the carotenoids such as $\beta$-carotene and total carotenoid production has been increased through silencing of $\beta$ carotene hydroxylase gene. As potato tuber contain low level of carotenoids which mainly composed of xanthophylls lutein and viloxanthin. But none of these compounds has provitamins A activity. Only $\beta$-carotene is main precursor of vitamin $\mathrm{A}$.

\section{Utilization of RNAi for seedless organic product (Parthenocarpy)}

Phytohormones assume an urgent job in guideline of change between blossoming, preparation and fruiting. Parthenocarpy is fundamental for creating plant crops when fertilization and preparation is severally influenced by abiotic stress and yield is diminished. Accordingly to guarantee yield dependability in troublesome climatic condition parthenocarpic organic products required. An examination demonstrates that seedlessness in watermelon and brinjal increment the surface and self existence of natural products (Pandolfini. 2009).

Two individual from ARF family ARF8 and ARF7 show significant level of articulation in non-pollinated blossoms and down controlled after fertilization. In tomato plants, RNAi empowers constraint of gibberellic corrosive and auxin signal pathways after a decrease in the degree of SlARF7 transcript, which is answerable for fertilization and preparation
Table-1 (Jong et al., 2009). It by-pass the auxin flagging preparation pathway in tomato that prompts the advancement of parthenocarpic organic products, which has incredible business esteem in the current rural market and better return can be accomplished even natural conditions bothersome for fertilization and treatment. By downmanaging a chalcone synthase, a quality associated with flavonoid biosynthesis, seedless organic products have been accomplished in tomato. Phytohormones, for example, auxin and gibberellins are firmly connected with parthenocarpy in tomato which thusly is controlled by numerous miRNAs (Molesini et al., 2012). Accordingly, controlling the degree of phytohormones by controlling exercises of miRNAs or their objectives could end up being a viable way to deal with to get parthenocarpy natural products. Parthenocarpic natural products were likewise seen in tomato in which qualities of the AUCSIA family coding for 53-amino-corrosive long (protein or peptide) were practically smothered by RNAi (Molesini et al., 2009).

\section{RNAi for changed bloom shading}

By and by, request of blossoms has expanded for improvement and fragrance reason. Assortment of blossoms and fragrance has accessible in showcase as per purchaser need and inclination. A ton of research has been brought out to improve the blossoms through quality hushing (Table 1).

In chrysanthemum work has been done to expand the splendor in petals through RNAi. Two chrysanthemum cultivars, $\mathrm{C} \times$ morifolium 'LPi' and $\mathrm{C} \times$ morifolium 'LPu', that just gather flavonoids in their ligulae blossoms used to disengaged seven anthocyanin biosynthesis qualities for example CmCHS, $\mathrm{CmF3H}, \quad \mathrm{CmF}^{\prime} \mathrm{H}$, CmDFR, CmANS, CmCHI and $\mathrm{Cm} 3 \mathrm{GT}$ in 
these cultivars. RT-PCR and qRT-PCR examinations demonstrated that $\mathrm{CmF}^{\prime} \mathrm{H}$ was the most significant compound required for cyanidin biosynthsis. To remake the delphinidin pathway, the down guideline of CmF3'H utilizing RNAi and over communicated the Senecio cruentus $\mathrm{F}^{\prime} 5^{\prime} \mathrm{H}$ (PCFH) quality in chrysanthemum exhibited an altogether expanded substance of cyanidin and more splendid red blossom petals however didn't aggregate delphinidin. These outcomes showed that $\mathrm{CmF}^{\prime} \mathrm{H}$ in chrysanthemum is significant for anthocyanin gathering, and Senecio cruentus F3'5'H just displayed $\mathrm{F}^{\prime} \mathrm{H}$ action in chrysanthemum however didn't modify the delphinidin pathway to shape blue bloom chrysanthemum (Huang et al., 2013).

\section{Infection resistance through RNAi}

Plant pathogen inferred (PDR) is the most remarkable way to deal with battle infection disease in plants. The utilization of PDR idea has assisted with designing infection safe plants (Simon-Mateo and Garcia 2011). Another system dependent on the utilization of miRNA develop that express various fake miRNA (amiRNA) focusing on different district of a viral quality. RNAi interceded coat protein (CP) quality of infections is likewise seen as very compelling in prompting protection from the plant against infections. Infection obstruction has been built effectively by focusing on the coat protein (CP) quality through RNAi in numerous green plants. Transgenic tobacco communicating the $\mathrm{CP}$ quality of Tobacco Mosaic Virus (TMV) was impervious to TMV and that the obstruction was because of the communicated Coat Protein as appeared by Powell-Abel et al., (1986). After, this technique was applied to produce obstruction against a few distinctive infections, for example, potato impervious to Potato Virus Y (PVY) by Missiou et al., 2004. Cucumis cv. melo impervious to Papaya Ring Spot Virus type W(PRSV-W) by Krubphachaya et al., 2007 and Prunus domestica impervious to Plum Pox infection (PPV) (Hily et al., 2007).

Comparative technique was utilized to effectively design obstruction in cassava plants against African Cassava Mosaic Virus (ACMV); Vanderschuren et al., 2009). RNA quieting procedure isn't restricted to RNA infections yet can effectively be applied to DNA infections to design obstruction. In blackgram plants recouped effectively from geminivirus Vigna mungo yellow mosaic infection (VMYMV) contamination when immunized with hpRNA develop containing the advertiser succession of VMYMV heavily influenced by the $35 \mathrm{~S}$ advertiser (Pooggin et $a l ., 2003)$. RNAi strategy has been utilized to produce basic bean impervious to geminivirus Beans Golden Mosaic Virus (BGMV) (Bonfim et al., 2007). A wide-range of opposition has been created against tospoinfections by focusing on different districts of a viral quality in tomato plants (Bucher et al., 2006).

\section{RNAi for Insect and nematode opposition}

Creepy crawly bugs cost billions of dollars in type of yield misfortunes and pesticide. Still people groups face an ever present danger of bug spray and host opposition. Every year crop loss of worth US\$125 billion was accounted for by unmanageable phytoparasitic nematodes. Gheysen and Vanholme (2007) showed that ds-RNA articulation in a host plant against housekeeping or parasitism qualities in the root-tie nematode brings about nematode safe plants.

Huang et al., (2006) were first to show protection from more than one nematode animal types, focusing on a quality engaged with parasitism instead of a nematode 
housekeeping quality. All things considered, late sequencing of the Meloidogyne hapla genome will uncover new focuses for HDRNAi (Oppermana et al., 2008).

Through host-instigated RNAi (Sindhu et al., 2009) directed every one of the four nematode parasitism qualities of sugar beet sore nematode (Heterodera schachtii), 3B05, 4G06, 8H07 and 10A06, having host A. thaliana. They revealed that no total obstruction was watched, however it prompted 23-64\% decrease in the quantity of develop nematode females in various RNAi lines.

Ibrahim et al., (2011) they directed four distinct qualities for RNAi develops (Ibrahim et al., 2011). The qualities have high comparability with Heterodera glycines (basic soybean blister nematode) and C. elegans to decide their viability to diminish nerves shaped by Meloidogyne incognita in soybean roots. Of the four, two develops focusing on the qualities encoding tyrosine phosphatase (TP) and mitochondrial stress-70 protein antecedent (MSP) had the option to decrease nerve arrangement by 92 and $94.7 \%$, separately.

Colorado potato bugs are a feared bug of potatoes shielded from herbivory utilizing RNA obstruction (RNAi). They hereditarily changed plants to empower their chloroplasts to aggregate twofold stranded RNAs (dsRNAs) directed against fundamental bug qualities.

\section{RNAi for parasitic and bacterial opposition}

Organism and microorganisms are most dangerous plant pathogen and perhaps the greatest test to specialists. They spread exceptionally quick and become hard to control. RNAi is one way to deal with upgrading parasitic and bacterial obstruction in plants. Escobar et al., (2001) demonstrated that hushing of two bacterial qualities (iaaM and ipt) could diminish the creation of crown nerve tumors (AGROBACTERIUM TUMEFACIENS) to about zero in Arabidopsis proposing that protection from crown nerve sickness could be designed in trees and decorative plants. In 2010, Xin et al., announced that 24 miRNAs were receptive to fine buildup disease brought about by the commit biotrophic parasite Blumeria graminis $f$. sp. tritici. What's more, further anti-cipated 149 objective qualities which were conceivably managed by the novel wheat mi-RNA.

\section{Decreased allergenicity and lethality through RNAi}

Nourishment hypersensitivity is a misrepresented insusceptible reaction of our body activated by allergens present in nourishment, for example, peanuts, apple, mango or some other explicit nourishment. Along these lines, there is a need to diminish or take out the substance of allergens from our nourishment. Not just this, there is likewise a need to create plants liberated from dangerous substances as the regular poisons are available in a wide assortment of plants usually devoured as nourishment. These lethal substances when ingested in noteworthy sum or when they are not handled suitably can be possibly hurtful to human wellbeing causing food contamination. The end of allergens and harmful substances can be accomplished by utilizing RNA obstruction that may adjust the biosynthesis of allergens by changing its biochemical pathway to improve the nourishment quality by limiting the danger of nourishment hypersensitivity and harmfulness.

Nourishment hyper-sensitivity is an exaggerated invulnerable reaction of our body activated by allergens present in nourishment and green plants. So there is expected to wipe out of allergens and harmful substances by 
utilizing RNAi that modify the biosynthesis of allergens by adjusting its biochemical pathway to improve the nourishment quality. RNAi has fundamental and intense innovation to build's plant with diminished allergencity and harmfulness. To quiet the particular allergens and poisonous metabolites, RNAi is profoundly productive due its succession explicitness to specific allergens without hampering the fundamental cell compound. In apple (Malus domestica), an allergen known as mal d1 articulation has been diminished through RNAi approach. Mal d1 cross response immunizer is IgE, cause unfriendly response in patients. To manufacture the RNAi build for powerful hushing mal $\mathrm{d} 1$ quality, an intron containing mal d1 quality was confined from cultivars known as Gala. The outcomes show that a wild-type plantlet had altogether $(\mathrm{P}<.05)$ higher allergenicity than 5 of the change plants. The decrease of articulation of Mal d 1 was affirmed by immunoblotting and skin prick trial of apple pamphlet (Gilissen et al., 2005). In another examination, the outflow of allergen Lyc e 3, which encodes a vague lipid move protein (ns-LTP) in tomato plants, was decreased through explicit dsRNAi build of LTPG1 and LTPG2 (Le LQ et al., 2006).

Smothered lfs quality by hp-RNAi utilizing 35S CaMV advertiser decreasing LFS movement in injured onion bringing about the creation of tearless onion (Eady et al., 2008).

An utilized RNAi to stifle the cytochrome P450 protein creation hindering the biosynthesis of linamarin and lotaustralin, and produced transgenic cassava (Manihot esculenta) plants with disposal of under $1 \%$ of cyanogenic glucosides from leaves and $92 \%$ decrease of cyanogenic glucosides from tubers (Jorgensen et al., 2005) (Fig. 1).

Table.1 Gene targeted for RNAi-mediated crop improvement in horticultural plants

\begin{tabular}{|c|c|c|c|c|c|}
\hline $\begin{array}{l}\text { S. } \\
\text { No. }\end{array}$ & $\begin{array}{l}\text { Crop } \\
\text { improvement }\end{array}$ & Plant used & Traits improved & Gene targeted & References \\
\hline \multirow[t]{4}{*}{1} & \multirow[t]{4}{*}{ Bio-fortification } & Tomato & $\begin{array}{l}\beta \text {-Carotene } \\
\& \text { lycopene }\end{array}$ & NCED1 & (Sun et al., 2012) \\
\hline & & Tomato & $\begin{array}{l}\text { Carotenoid \& } \\
\text { flavonoid }\end{array}$ & DET 1 & $\begin{array}{l}\text { (Davuluri et al., } \\
\text { 2005) }\end{array}$ \\
\hline & & Potato & $\begin{array}{l}\beta \text {-Carotene \& } \\
\text { lutein }\end{array}$ & $\mathrm{BCH}$ & (Eck et al., 2007) \\
\hline & & Tomato & Vitamin C & APX & $\begin{array}{l}\text { (Zhang et al., } \\
\text { 2011) }\end{array}$ \\
\hline \multirow[t]{2}{*}{2} & \multirow[t]{2}{*}{ Bio-elimination } & Coffea canephora & Caffeine & CaMXMT 1 & (Ogita et al., 2003) \\
\hline & & Papaver somniferum & Morphine & $\begin{array}{l}\text { Codeine } \\
\text { Reductase } \\
\text { (COR) }\end{array}$ & (Allen et al., 2004) \\
\hline \multirow[t]{4}{*}{3} & \multirow[t]{4}{*}{$\begin{array}{l}\text { Altered } \\
\text { phenotype }\end{array}$} & $\begin{array}{l}\text { Torenia hybrida cv. } \\
\text { Summerwave Blue }\end{array}$ & $\begin{array}{l}\text { Flower colour: } \\
\text { blue to white }\end{array}$ & CHS & $\begin{array}{l}\text { (Fukusaki et al., } \\
\text { 2004) }\end{array}$ \\
\hline & & Petunia & $\begin{array}{l}\text { Scent profile } \\
\text { modification }\end{array}$ & $\mathrm{PhBSMT}$ & $\begin{array}{l}\text { (Underwood et al., } \\
\text { 2005) }\end{array}$ \\
\hline & & Tomato & \multirow[t]{2}{*}{ Parthenocarpy } & AUCSIA & $\begin{array}{l}\text { (Molesini et al., } \\
\text { 2009) }\end{array}$ \\
\hline & & Tomato & & CHS & $\begin{array}{l}\text { (Schijlen et al., } \\
\text { 2007) }\end{array}$ \\
\hline
\end{tabular}


Table.2 Name of horticultural crops and varieties in which transgenic developed (Xiong et al., 2015)

\begin{tabular}{|c|c|c|c|}
\hline S.No & Crops & Variety & Characters \\
\hline \multirow[t]{2}{*}{1} & Papaya & Rainbow, SunUp & Disease resistance \\
\hline & & Huanong No. 1 & \\
\hline \multirow[t]{2}{*}{2.} & Apple & Golden Delicious & Modified product quality \\
\hline & & Granny Smith & Non-browning phenotype \\
\hline \multirow[t]{2}{*}{3.} & Plum & $\mathrm{C}-5$ (NA) & Disease resistance \\
\hline & Grape & & \\
\hline 4. & Tomato & $\begin{array}{l}\text { Da Dong No } 9 \text { (NA), Huafan No } 1 \text { (NA), } \\
\text { FLAVR SAVR }\end{array}$ & Modified product quality \\
\hline 5. & Brinjal & Bt Brinjal Event EE1 & Insect resistance \\
\hline \multirow[t]{3}{*}{6.} & Potato & $\begin{array}{l}\text { Lugovskoi plus, Atlantic } \\
\text { NewLeaf2 potato) }\end{array}$ & Insect resistance \\
\hline & & Starch Potato, Innate2 Russet Burbank Potato & Modified product quality \\
\hline & & $\begin{array}{l}\text { New Leaf } 2 \text { Y Russet Burbank potato, New } \\
\text { Leaf } 2 \text { Plus Russet Burbank potato) }\end{array}$ & Insect + disease resistance \\
\hline \multirow[t]{2}{*}{7.} & Sweet pepper & PK-SP01 (NA) & Disease resistance \\
\hline & & New Leaf2 Plus Russet Burbank potato & \\
\hline 8. & Rose & WKS82/130-4-1 (NA) & Modified product quality \\
\hline \multirow[t]{10}{*}{9.} & Carnation & Moondust & Modified product quality \\
\hline & & Moonshadow & $\begin{array}{l}\text { Herbicide tolerance } 1 \text { modified } \\
\text { product quality }\end{array}$ \\
\hline & & Moonshade & \\
\hline & & Moonlite & \\
\hline & & Moonaqua & \\
\hline & & Moonvista & \\
\hline & & Moonique & \\
\hline & & Moonpearl & \\
\hline & & Moonberry & \\
\hline & & Moonvelvet & \\
\hline 10. & Petunia & Petunia-CHS & Modified product quality \\
\hline 11. & $\begin{array}{l}\text { Creeping } \\
\text { Bentgrass }\end{array}$ & $\begin{array}{l}\text { Roundup Ready Creeping } \\
\text { Bentgrass }\end{array}$ & Herbicide tolerance \\
\hline
\end{tabular}


Fig.1 Post-transcriptional gene silencing (PTGS) in plants triggered by single transgene expression above a threshold level or by inverted repeat transcription. The single transgene transcript is converted into aberrant RNA and subsequently transformed into double-stranded RNA (dsRNA). The viral PTGS inhibitor acts by activation of regulator of gene silencingCalmodulin-related protein (rgsCAM), a cellular PTGS inhibitor

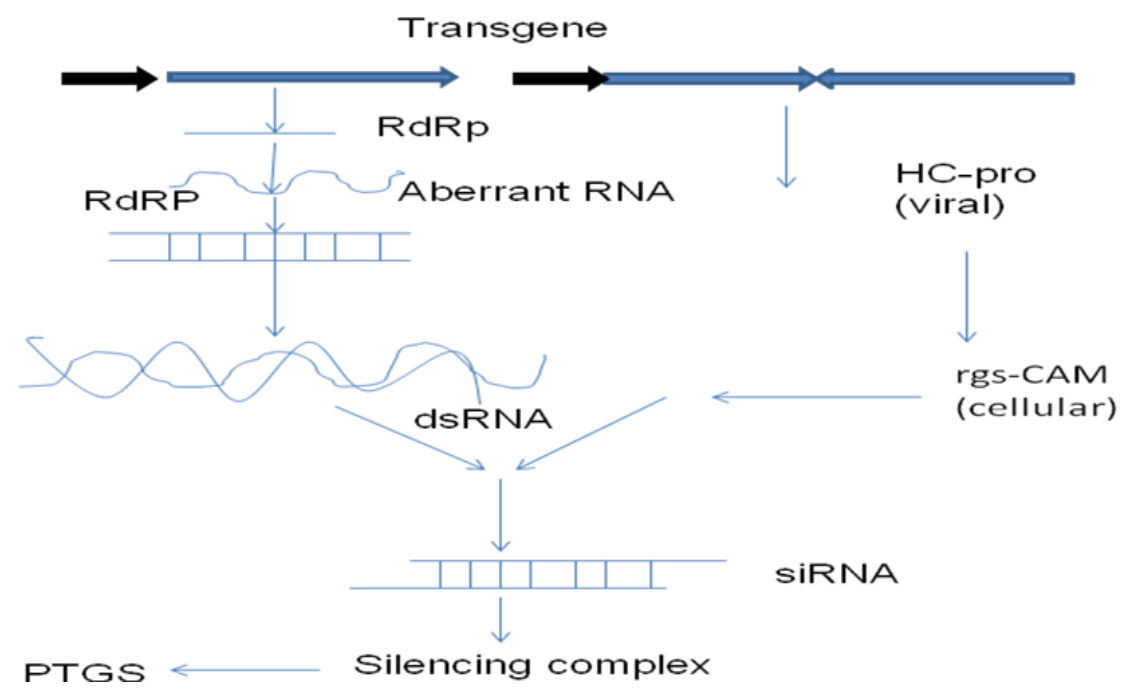

\section{RNAi for abiotic stress resistance}

Abiotic stress is a genuine danger for the life on earth, especially plants whose development and yield influenced contrarily. Plants have adjusted various physiological, bio-compound and metabolic methodologies to experience the abiotic stresses. Typically, it is dubious to conceive the convoluted pathway of flagging that are animated and killed in light of various abiotic stresses (Chawla et al., 2011). Current discoveries showed that RNAi is assuming a basic job in abiotic stresses incitement in various harvests. The capacity of miRNAs (microRNA) corresponding to abiotic stress like oxidative pressure, cold, dry spell, and saltiness were accounted for by Sunker and Zhu (2004). Moreover, miR402, miR319c, miR397b, and miR389a were constrained by abiotic worry under differing levels in Arabidopsis (Jagtap et al., 2011).

Quality hushing forms have been generally misused as adaptable exploratory and biotechnological instruments for utilitarian quality examinations and transgenic ways to deal with crop improvement, infection obstruction, and metabolic building. In number of cultivation transgenic crops has created against a few biotic and abiotic stress resistances (Table 2).

\section{Application of RNAi in transgenic plants}

RNA interference (RNAi) is an evolutionary conserved gene regulatory approach that has significant impact on crop improvement; it permits down-regulation in gene expression with greater precise manner without affecting the expression of other genes. In the recent year the RNAi mediated technology has been used in metabolic engineering of plants with respects to improvement of various traits and to targets the genes linked to different undesired characters. In several plants RNAi has been used to improve their nutritional value, flavour, genetically modification of fatty acid composition and reduction toxicity/ allergencity in plants. The several application 
of RNAi approach has been an elaborated here in major consumed crops.

In conclusion all technology has its limits. Post-transcriptional RNA silencing generally does not lead to complete gene silencing. Furthermore, it is unclear whether RNA silencing technologies can be used to consistently inactivate endogenous gene promoters in plants, which, unlike transgene promoters, appear to be resistant to siRNAdirected transcriptional silencing. This would limit the applications of RNA silencing technologies, particularly in cases where complete and stable genetic deletion is required. Combinations of RNA silencing technologies based on different RNA silencing pathways could improve silencing efficiency. For example, combining PTGS with TGS-based technologies, siRNA with miRNA-based technologies, or technologies based on all the different RNA silencing pathways, could potentially lead to more potent gene silencing than using technologies based on a single track. Recent years have seen great advances in the development of technologies for site-directed mutagenesis in plants. Technology can now be used to mutagenesis or modify nucleotide sequences of selected genes or genomic loci in plants (CRISPR / Cas9). The complete deletion of essential genes is lethal to plants and therefore such mutants cannot be recovered by this technology like mutagenesis technologies.

However, mutants of such genes could be recovered for genetic function analysis by incomplete deletion of genes with RNA silencing technologies. This is demonstrated in rice, where transformation with shRNA libraries results in the recovery of essential genetic mutants. RNA silencing technologies allow for tissue-specific silencing of a gene using a transgene expressly expressed in the tissue, while the genetic mutation causes inactivation of the gene in all tissues. iv) RNA silencing technologies can be used to simultaneously silence multiple genes using transgenes that contain a conserved sequence or a composite sequence of multiple genes, while this would be difficult to achieve using CRISPR / Cas9-like mutagenesis methods. With continued efforts to better understand RNA silencing mechanisms in plants, it can be expected that RNA silencing technologies will be further improved to overcome the potential limitations that allow for wider applications in agriculture. RNAi has become a highly effective experimental tool in functional genomics for silencing genes for both basic and applied biological studies in various organisms including plants. RNAi deploys small RNAs, mainly siRNAs, to mediate the degradation of mRNA for regulating gene expression in plants. However, RNAi stability in plants is critical, but the RNAi-mediated gene suppression approach opens new avenues for the development of eco-friendly biotech approaches for crop improvement. By way of knocking out of the specific genes for better stress tolerance and integrating novel traits in different plant species for insect/pest/pathogen resistance and enhanced nutritional status become more convenient rather than convectional practices. This technology having revolutionary capabilities could be further exploited for functional analysis of target genes and regulation of gene expression for crop improvement.

\section{References}

Allen, R.S., Miligate, A.G., Chitty, J.A., Thisleton, J., Miller, J.A.C., First, A.J., Gerlach, W.L., and Larkin, P.J., 2004. RNAi mediated replacement of morphine with non narcotic alkaloids reticuline in opium poppy. Nat Biotechnol 22, 559-66.

Bonfim, K., Faria, J.C., Nogueira, E.O., Mendes, E.A., and Aragao, F. J., 2007. RNAi mediated resistance to bean golden mosaic virus in genetically engineered common 
bean (Phaseolus vulgaris). Mol Plant Microbe Interact 20, 717-726. doi: 10.1094/MPMI-20-6-0717

Bucher, E., Lohius, D., van Poppel, P.M., GeertsDimitriadou, C., Gold-bach, R., and Prins, M., 2006. Multiple virus resistance at a high frequency using a single transgene construct. J Gen Virol 87, 697-701.

Chawla, K., Barah, P., Kuiper, M.,and Bones, A.M., 2011. Systems biology: a promising tool to study abiotic stress responses. in: N. Tuteja, S. Gill, R. Tuteja (Eds.), Omics and Plant Stress Tolerance, Benjam Science Publisher, USA, pp. 163-172.

Chen, S., Hajirezaei, M.R., Zanor, M.I., Hornyik, C., Debast, S., Lacomme, C., Fernie, A.R., Sonnewald, U., and Bornke, F., 2008. RNA interference- mediated repression of sucrose-phosphatase in transgenic potato tubers (Solanum tuberosum) strongly affects the hexoseto- sucrose ratio upon cold storage with only minor effects on total soluble carbohydrate accumulation. Plant Cell Environ 31, 165-176.

Choudhary, S., Jain, D., Meena, M.R., Verma, A.K., and Sharma, R., 2018. Gene Silencing in Horticultural Transgenic Crops. In: Rout, G.R., Peter, K.V. (Eds.), Genetic Engineering of Horticultural Crops. Academic Press, Elsevier pp. 4761.

Dandekar, A.M., Teo, G., Defilippi, B.G., Uratsu, S.L., Passey, A.J., Kader, A.A., Stow, J. R., Colgan, R.J., and James, D.J., 2004. Effect of down-regulation of ethylene biosynthesis on fruit flavor complex in apple fruit. Transgenic Res 13, 373-384.

Davuluri, G.R., van Tuinen, A., Fraser, P.D., Manfredonia, A., Newman, R., Burgess, D., Brummell, D.A., King, S.R., Palys, J., Uhlig, J., Bramley, P.M., Pennings, H.M., and Bowler, C., 2005. Fruit-specific RNAi-mediated suppression of DET1 enhances carotenoid and flavonoid content in tomatoes. Nat Biotechnol 23, 890-895.

Eady, C.C., Kamoi, T., Kato, M., Porter, N.G., Davis, S., Shaw, M., Kamoi, A., and Imai, S., 2008. Silencing onion lachrymatory factor synthase causes a significant change in the sulfur secondary metabolite profile. Plant Physiol 147, 2096-2106.
Eck, J.V., Conlin, B., Garvin, D.F., Mason, H., Navarre, D.A., and Brown, C.R., 2007. Enhancing beta-carotene content in potato by RNAi mediated silencing of the betacarotene hydroxylase gene. Am J Potato Res 84, 331-342.

Escobar, M.A., Civerolo, E.L., Summerfelt, K.R., and Dandekar, A.M., 2001. RNAimediated oncogene silencing confers resistance to crown gall tumorigenesis. Proc Natl Acad Sci USA 98, 1343713442.

Fukusaki, E., Kawasaki, K., Kajiyama, S., An, C.I., Suzuki, K., Tanaka, Y., and Kobayashi, A., 2004. Flower color modulations of Torenia hybrida by down regulation of chalcone synthase genes with RNA interference. J Biotechnol 111, 229240.

Gheysen, G., and Vanholme, B., 2007. RNAi from plants to nematodes. Trends Biotechnol 25, 89-92.

Gilissen, L.J., Bolhaar, S.T., Matos, C., Boone, M.J., Krens, F.A., Zuidmeer, L., Van Leeuwen, A., Akkerdaas, J., HoffmannSommergruber, K., Knulst, A.C., Bosch, D., Van de Weg, W.E., and Van Ree, R.. 2005. Silencing the major apple allergen Mal d1 by using the RNA interference approach. J Allergy Clin Immunol 115, 364-379.

Gupta, A., Pal, R.K., and Rajama, M.V., 2013. Delayed ripening and improved fruit processing quality in tomato by RNAimediated silencing of three homologs of 1aminopropane-1-carboxylate synthase gene. J Plant Physiol 170, 987-995.

Hily, J. M., Ravelonandro, M., Damsteegt, V., Basset, C., Petri, C., Liu, Z., and Scorza, R., 2007. Plum pox virus coat protein gene intron-hair pin-RNA (ihpRNA) constructs provide resistance to Plum pox virus in Nicotiana bethamiana and Prunus domestica. J Am Soc Hort Sci 132, 850858.

Hoffmann, T., Kalinowski, G., and Schwab, W., 2006. RNAi-induced silencing of gene expression in strawberry fruit (Fragaria $\mathrm{x}$ ananassa) by agroinfiltration: a rapid assay for gene function analysis. Plant J 48, 81826. 
Huang, G., Allen, R., Davis, E.L., Baum, T.J., and Hussey, R.S., 2006. Engineering broad root-knot resistance in transgenic plants by RNAi silencing of a conserved and essential root-knot nematode parasitism gene. Proc Natl Acad Sci USA 103, 14302-14306.

Ibrahim, H.M.M., Alkharouf, N.W., Meyer, S.L.F., Aly, M.A.M., El-Din, A.E.K.Y.G., Hussein, E.H.A., and Matthews, B.F., 2011. Post-transcriptional gene silencing of root-knot nematode in transformed soybean roots. Exp Parasitol 127, 90-99.

Jagtap, U.B., Gurav, R.G., and Bapat, V.A., 2011. Role of RNA interference in plant improvement. Naturwissenschaften 98, 473-492.

Jorgensen, K., Bak, S., Busk, P.K., Sorensen, C., Olsen, C.E., Puonti-Kaerlas, J., and Moller, B.L., 2005. Cassava plants with a depleted cyanogenic glucoside content in leaves and tubers. Plant Physiol 139, 363374.

Karlova, R., van Haarst, J. C., Maliepaard, C., van de Geest, H., Bovy, A. G., Lammers, M., Angenent, G.C., and de Maagd, R.A., 2013. Identification of microRNA targets in tomato fruit development using highthroughput sequencing and degradome analysis. J Exp Bot 64, 1863-1878.

Krubphachaya, P., Jurícek, M., and Kertbundit, S., 2007. Induction of RNA mediated resistance to papaya ring spot virus type W. J Biochem Mol Biol 40, 401-411.

Le, L.Q., Lorenz, Y., Scheurer, S., Fotisch, K., Enrique, E., Bartra, J., Biemelt, S., Vieths, S., and Sonnewald, U., 2006. Design of tomato fruits with reduced allergenicity by dsRNAi-mediated inhibition of ns-LTP (Lyc e 3) expression. Plant Biotechnol J 4, 231-42.

Meli, V.S., Ghosh, S., Prabha, T.N., Chakraborty, N., Chakraborty, S., and Datta, A., 2010. Enhancement of fruit shelf life by suppressing $\mathrm{N}$-glycan processing enzymes. Proc Natl Acad Sci U.S.A. 107, 2413-2418.

Missiou, A., Kalantidis, K., Boutla, A., Tzortzakaki, S., Tabler, M., and Tsagris, M., 2004. Generation of transgenic potato plants highly resistant to potato virus $\mathrm{Y}$
(PVY) through RNA silencing. Mol Breed 14, 185-197.

Molesini, B., Pandolfini, T., Rotino, G.L., Dani, V., and Spena, A., 2009. Aucsia gene silencing causes parthenocarpic fruit development in tomato. Plant Physiol 149, 534-548.

Molesini, B., Pii, Y., and Pandolfini, T., 2012. Fruit improvement using intragenesis and artificial microRNA. Trends Biotechnol 30, 80-88.

Niggeweg, R., Michael, A.J., and Martin, C., 2004. Engineering plants with increased levels of the antioxidant chlorogenic acid. Nat Biotechnol 22, 746-754.

Ogita, S., Uefuji, H., Yamaguchi, Y., Koizumi, N., and Sano, H., 2003. Producing decaffeinated coffee plants. Nature 423, 823.

Oppermana, C.H., Bird, D.M., Williamson, V.M., Rokhsar, D.S., Burke, M., Cohn, J., Cromer, J., Diener, S., Gajan, J., Graham, S., Houfek, T.D., Liu, Q., Mitros, T., Schaff, J., Schaffer, R., Scholl, E., Sosinski, B.R., Thomas, V.P., and Windham, E., 2008. Sequence and genetic map of Meloidogyne hapla: a compact nematode genome for plant parasitism. Proc Natl Acad Sci USA 105, 1480221480.

Pandolfini, T., 2009. Seedless fruit production by hormonal regulation of fruit set. Nutrients 1, 168-177.

Pooggin, M., Shivaprasad, P.V., Veluthambi, K., and Hohn, T., 2003. RNAi targeting of DNA virus in plants. Nat Biotechnol., 21, 131-132.

Powell-Abel, P., Nelson, R.S., De, B., Hoffmann, N., Rogers, S.G., Fraley, R.T., and Beachy, R.N., 1986. Delay of disease development in transgenic plants that express the tobacco mosaic virus coat protein gene. Science. 232, 738-743.

Schijlen, E.G.W.M., De-Vos, R.C.H., Martens, S., Jonker, H.H., Rosin, F.M., Molthoff, J.W., Tikunov, Y.M., Angenent, G.C., VanTunen, A.J., and Bovy, A.G., 2007. RNA interference silencing of chalcone synthase, the first step in the flavonoid biosynthesis pathway, leads to parthenocarpic tomato fruits. Plant Physiol 
144:1520-1530.

Sharda Choudhary, Devendra Jain Mintu R. Meena, Arvind K.Verma, Radheshyam Sharma Chapter 3-Gene Silencing in Horticultural Transgenic Crops https://doi.org/10.1016/B978-0-12810439-2.00003-9

Simon-Mateo, C., and Garcia, J.A., 2011. Antiviral strategies in plants based on RNA silencing. Biochim Biophys Acta. 1809, 722-731.

Sindhu, A.S., Maier, T.R., Mitchum, M.G., Hussey, R.S., Davis, E.L., and Baum, T.J., 2009. Effective and specific in planta RNAi in cyst nematodes: expression interference of four parasitism genes reduces parasitic success. J Exp Bot 60, 315-324.

Sun, L., Yuan, B., Zhang, M., Wang, L., Cui, M., Wang, Q., and Leng, P., 2012. Fruitspecific RNAi-mediated suppression of SINCED1 increases both lycopene and bcarotene contents in tomato fruit. J Exp Bot. doi:10.1093/jxb/ers026.

Sunkar, R., and Zhu, J.K., 2004. Novel and stressregulated micro RNAs and other small RNAs from Arabidopsis. Plant Cell 16, 2001-2019.

Underwood, B.A., Tieman, D.M., Shibuya, K., Dexter, R.J., Loucas, H.M., Simkin, A.J., Sims, C.A., Schmelz, E.A., Klee, H.J., and Clark, D.G., 2005. Ethylene-regulated floral volatile synthesis in petunia corollas. Plant Physiol 138, 255-266

Vanderschuren, H., Alder, A., Zhang, P., and Gruissem, W., 2009. Dose-dependent RNAi-mediated geminivirus resistance in the tropical root crop cassava. Plant Mol Biol., 70, 265-272.

White, P.J., and Broadley, M.R., 2009. Biofortification of crops with seven mineral elements often lacking in human diets-iron, zinc, copper, calcium, magnesium, selenium and iodine. New Phytol., 182, 49-84

Xin, M., Wang, Y., Yao, Y., Xie, C., Peng, H., Ni, Z., and Sun, Q., 2010. Diverse set of microRNAs are responsive to powdery mildew infection and heat stress in wheat (Triticum aestivum L.). BMC Plant Biol., 10, 123.

Xiong, J.S., Ding, J., and Li, Y., 2015. Genomeediting technologies and their potential application in horticultural crop breeding. Horticulture Research 2, 15019. doi:10.1038/hortres.2015.19

Zhang, Y.Y., Li, H.X., Shu, W.B., Zhang, C.J., and Ye Z.B., 2011. RNA interference of a mitochondrial APX gene improves vitamin $\mathrm{C}$ accumulation in tomato fruit. Scientia Hort. 129, 220-226.

\section{How to cite this article:}

Choudhary, S., S. K.Barolia, R. Sharma, R. S. R. Krishnan, M. R. Hindala and Sewda, M. 2020. Gene Silencing in Horticultural Transgenic Plants: Mechanisms, Technologies and Applications in Horticultural Crops. Int.J.Curr.Microbiol.App.Sci. 9(11): 1040-1052. doi: https://doi.org/10.20546/ijcmas.2020.911.122 